\title{
GLACIER CAVES: A GLOBALLY THREATENED SUBTERRANEAN BIOME
}

\author{
Francis G. Howarth ${ }^{1}$
}

\section{Abstract}

Caves and cave-like voids are common features within and beneath glaciers. The physical environment is harsh and extreme, and often considered barren and devoid of life. However, accumulating evidence indicates that these caves may support a diverse invertebrate fauna with species endemic to each region. As glaciers continue to disappear at an alarming rate due to global warming, they take their largely unknown fauna with them. Thus, glacier caves may harbor one of the most endangered ecosystems globally, and yet their biodiversity is among the least studied or known. Faunal surveys and ecological studies are urgently needed before all examples are lost.

\section{INTRODUCTION}

Glacier caves are voids within and beneath glaciers that are formed mostly by surface meltwater sinking into the glacier through crevasses, moulins, and fissures (Piccini and Mecchia, 2013; Smart, 2003; Kováč, 2018; Gulley and Fountain, 2019). Glacier caves can be enlarged by geothermal melting (Kiver and Mumma, 1971; Giggenbach, 1976), as well as by pressure and friction at the contact between the ice and bedrock. These caves are created by natural phenomena during the life of the glacier and are common features in glaciers. They are best developed in montane glaciers in comparison to polar glaciers, largely because of the steeper gradient, greater flow rate, and seasonally warmer temperatures (Smart, 2003). The cave structure is dynamic; for example, changing shape and course as the glacier flows downslope; enlarging during warm periods; and collapsing and deforming under pressure. However, the voids within sediments at the base of glaciers may remain open and contain liquid water during most of the life of the glacier (Hodson et al., 2015) especially in montane glaciers at low and mid latitudes (Hotaling et al., 2017b). A meltwater stream often flows along the contact between the glacier and bedrock. This meltwater exits glaciers through springs and seeps that feed surface streams. Glacier caves are distinct from 'ice caves' (the latter more accurately referred to as 'freezing caverns'), which are conventional caves in rock ,such as limestone and basalt, that trap cold air and contain permanent ice (Kováč, 2018; Perşoiu and Lauritzen, 2018). The known fauna of freezing caverns was reviewed by lepure (2018).

Glacier caves can be considered a subgroup of the larger subterranean biome, as well as a subgroup of the glacial biome (Anesio et al., 2017). The latter is a subgroup of the aeolian biome (Papp, 1978; Swan, 1992). A biome is a grouping of ecosystems that share similar features of their physical environment and characteristics of the resident community of organisms. The physical environment within glacier caves is extreme. Temperatures remain near or below freezing, and the polished ice walls often appear clean and devoid of organic material. There are few food resources visible that could support life. Liquid water necessary for cellular function would be unavailable except during periods when meltwater is present. Shallow glacier caves receive subdued sunlight filtered through the translucent ice, but deeper caves remain completely dark (Hotaling et al., 2017b). Subglacial sediments are normally anoxic unless refreshed by incoming aerated surface water (Hodson et al., 2015). In addition, survey of subglacial habitats can be extremely difficult and dangerous (Hodson et al., 2015; Gulley and Fountain, 2019; Templeton and Jahn, 2019).

The barren appearance is deceiving. Organic material can be relatively abundant. The surface of glaciers traps wind-borne organisms and organic detritus that become encased in the ice when covered by new snow fall (Mani, 1968; Papp, 1978; Edwards, 1987; Lockwood et al., 1991; Cartaya and McGregor, 2014; Vanlooy and Vandeberg, 2019). The organic material is preserved often for millennia within the ice until meltwater releases it and washes it into caves or it is released at the margin of receding glaciers (Mani, 1968). The interface between the ice and bedrock under montane glaciers contains relatively abundant nutrient resources that support distinct and diverse microbial communities (Bhatia et al., 2006; Hodson et al., 2015; Hotaling et al., 2017b).

Meltwater on the glacial surface support diverse assemblages of microbiota on nearly all glaciers studied worldwide (Takeuchi 2011; Hotaling et al., 2017b). The main source of nutrients supporting these surface communities is transported by wind (Mani, 1968; Swan, 1992). Additional nutrients are contributed by autotrophic algae growing on the snow, but these organisms also require aeolian-derived nutrients for growth (Swan, 1992). These communities contribute significant organic material to meltwater that sinks into the glacier through crevasses and moulins (Hodson et al., 2015; Anesio et al., 2017; Hotaling et al., 2017b). The invertebrates are represented by five phyla: Rotifera, Annelida, Tardigrada, Nematoda, and Arthropoda (Zawierucha et al., 2015). Surprisingly, rotifers live on and in the snow and ice of glaciers in Iceland (Shain et al., 2016). A few macroscopic organisms exploit organic resources on the glacial surface, e.g., the obligate glacial ice worm, Mesenchytraeus solifugus on glaciers of northwestern North America (Hotaling et 
al., 2019) and numerous arthropods such as Arachnida, Collembola and Diptera in the Himalayas (Swan, 1992) and Plecoptera in Patagonia (Takeuchi 2011).

Meltwater exiting the downslope edge of glaciers feeds surface streams and springs. These glacially-fed surface waterways support a diverse fauna of cold-adapted aquatic invertebrates (Hotaling et al., 2017a) such as the Himalayas (Hamerlik and Jacobsen, 2011), New Zealand (Milner et al., 2001; Winterbourn et al., 2008), N. America (Giersch et al., 2016), S. America (Jacobsen et al., 2010), and Europe (Brown et al., 2007; Scotti et al., 2019). Most of the nutrients supporting this community is supplied by organic material exiting the glacier, at least close to the glacier forefront (Hotaling et al., 2017a). Although faunal surveys confirm the existence of a diverse fauna in glacially-fed streams, the true diversity remains unknown. In fact, most glaciers and associated surface water ways have yet to be surveyed, and as glaciers disappear through climate change, many species will be lost without having been described or recognized (Brown et al., 2007; Muhlfeld et al., 2011; Jacobsen et al., 2012; Giersch et al., 2015; Hotaling et al., 2017a; b; Jordan et al., 2016; Maurer et al., 2019; Zawierucha and Shain, 2019). For example, 125 of the estimated 150 glaciers have disappeared from Glacier National Park in the last 175 years, and by 2050, all of the iconic glaciers in the park will be gone (Hall and Fagre, 2003).

\section{FAUNA OF GLACIAL CAVES}

In contrast to these surface meltwater habitats, the harsh environment beneath glaciers has long been considered inhospitable and devoid of life. However, that view is changing with the discovery of microbial communities in subglacial lakes and within the sediments between the glacier and bedrock (Bhatia et al., 2006; Mikucki et al., 2009; Hotaling, 2017b). The macroinvertebrate fauna of subglacial habitats remains poorly known. I know of no overview of the fauna of any glacier cave, but at least a few subglacial arthropods are known. Two species of subterranean amphipods have been described from subglacial aquatic habitats in Iceland. Their endemism on the isolated oceanic island indicates that they survived in refugia (possibly maintained by geothermal heating) beneath glaciers (Kornobis et al., 2010). At least six species of cave-adapted amphipods in North America are thought to have persisted in subglacial refugia (Taylor and Niemiller, 2016), and in northern Europe several subterranean species of Niphargus amphipods most likely survived multiple glaciation events (Mclnerney et al., 2014). In addition to these aquatic species, a few terrestrial cave species survived glaciation including an anomalous cave-adapted campodeid dipluran that is known from the edge of the last glacial maximum on Vancouver Island, Canada (Sendra and Wagnell, 2019), and several species of collembola evidently survived glaciation in the British Isles (Faria, 2019). The habitat of these subglacial animals includes the medium-sized voids in the gravel between the glacier and bedrock, analogous to the "mesocaverns" in Howarth (1983). Liquid water may be available in this habitat by heating from a geothermal source, melting point reduction from pressure, and friction from the moving glacier. In August 1988, I visited Paradise Ice Cave in Paradise Glacier, Mt Rainier National Park (Fig. 1) and noted that in places the walls seemed alive with insects resting or running on the ice. I did not have a collecting permit, and as far as I know, the dozen or more species in four orders that I saw are still unknown. Observed were mayflies (Ephemeroptera), stoneflies (Plecoptera), caddisflies (Trichoptera), and flies and midges (Diptera). None of the species observed showed morphological characters that might indicate adaptation to subterranean habitats, and all may also occur in nearby melt water streams. However, because of their isolation within the glacier, most if not all species were successfully living in the cave. Due to glacial retreat from warming, Paradise Ice Cave is no longer accessible. Comprehensive surveys of aquatic insects were conducted by Kubo and colleagues (2012), and for stoneflies by Kondratieff and Lechleitner (2002) occurring in meltwater streams on Mt. Rainier; however, neither study apparently included glacial caves in their surveys. There is undoubtably significant overlap in the aquatic arthropod fauna of meltwater streams and the fauna within glacier caves, but there may be significant differences based on degree of isolation, food resources, age and history of the glacier, the source of fauna, and differences in the physical environment Even the meltwater stream fauna that successfully colonized glacier caves might have highly evolved additional physiological traits that allow them to survive in the harsh environment, such as being frozen for prolonged periods as well as being subjected to periodic anoxic conditions. For example, Bhatia et al. (2006) found that the bacterial communities beneath John Evans Glacier in Nunavut, Canada, were highly distinct from the composition of bacterial communities in adjacent supraglacial meltwater and ice-free proglacial sediments indicating that the bacterial community beneath the glacier were adapted to subglacial conditions.

The subglacial microbial communities along with aeolian debris and surface animals falling into subglacial voids would provide resources needed by cavernicoles. Animals that can exploit these resources and reproduce in subglacial voids would, over time, become adapted to life underground, possibly by an adaptive shift (Howarth et al., 2019). Potential candidates for colonizing aquatic subglacial habitats include the invertebrates inhabiting the glacial surface and glacial fed streams noted above. A potential source for terrestrial animals that could colonize glacial caves is the community of scavengers and predators living in talus slopes adjacent to snow fields. These animals characteristically venture onto the ice during favorable weather to feed on moribund aeolian waifs trapped on the ice. They retreat into the 


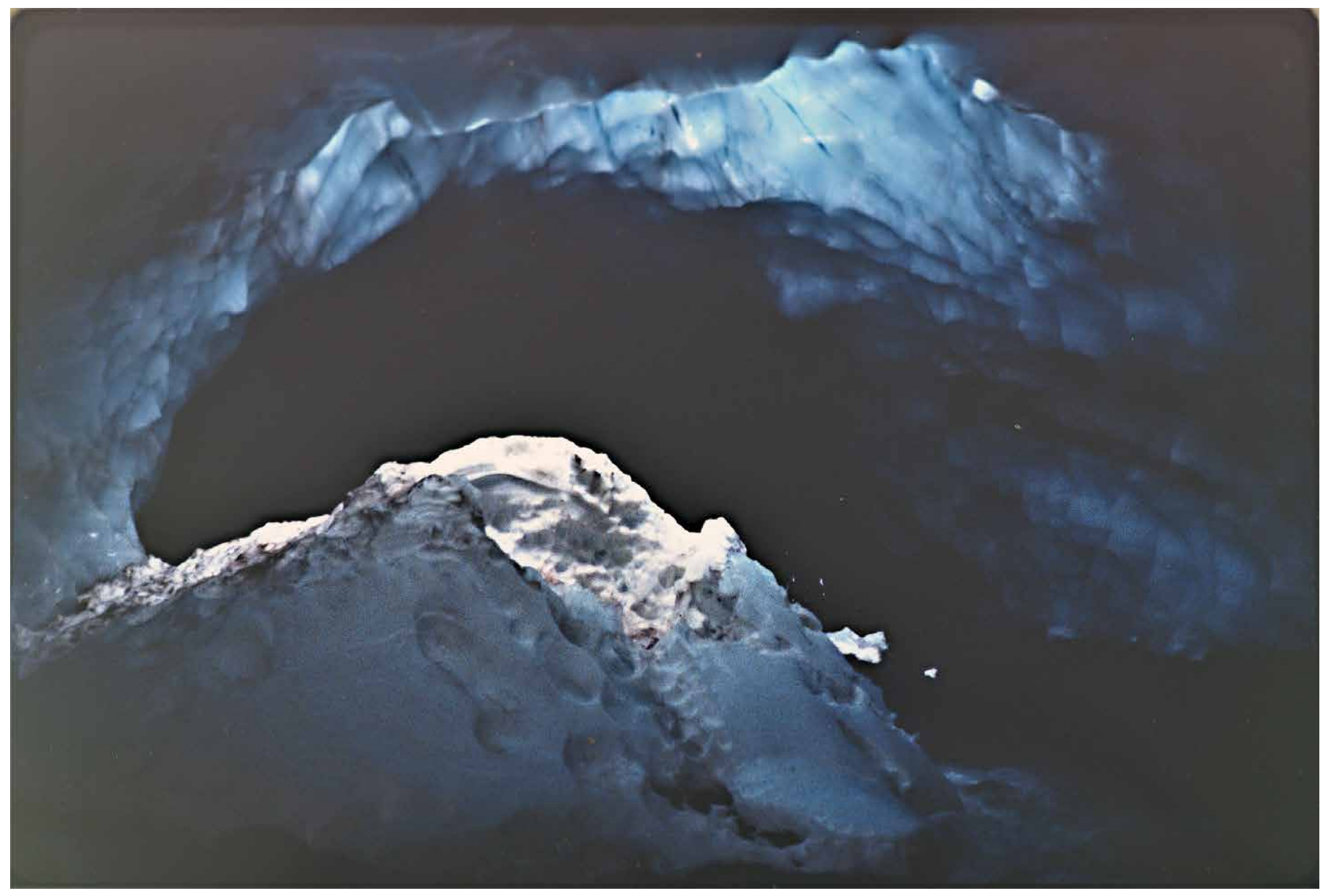

Figure 1. View downslope in Paradise Ice Cave, Mt. Rainier National Park, Washington, U.S.A. showing snow cone below skylight.

talus to escape unfavorable conditions (Edwards, 1987). These communities are dominated by cryophilic arthropods including spiders, harvestmen, springtails, grylloblattids, and staphylinid and carabid beetles (Mani, 1968; Edwards, 1987; Wipfler et al., 1914). Many of these cryophilic talus-inhabiting arthropods have close relatives adapted to live in conventional caves including freezing caverns (lepure, 2018). Without biological surveys, one cannot assume that these caves do not harbor unique animals (Ficetola et al., 2018). If these cave faunas were to go extinct before being studied, the assumption that nothing could possibly live there would remain true, and biologists could claim that they never existed. Our understanding of the fauna of glacial caves is currently analogous to the assumption pre-1970 that young lava tubes on oceanic islands were barren of life (Howarth, 1972). A diverse fauna including species highly specialized to live only underground in caves and similar habitats is now known from most temperate and tropical regions that have been adequately surveyed (Howarth, 1983; Howarth and Moldovan, 2018). The animals living in glacial caves provide unique research opportunities in evolutionary ecology, behavior and physiology. For example, how do the animals survive in such a harsh environment? Specifically, how long can glacier cave arthropods survive freezing? Meltwater streams maintain annual freezing and thawing cycles, and the surface stream fauna is known to survive in such regimes. The same temperature regime may not be true in glacier caves as slight prolonged cooling of the climate or collapse of passages may isolate the animals in frozen crypts for decades or centuries. How do animals disperse within or below the glacier? Which populations are permanent residents, and which are meta populations? The latter require periodic recolonization from surface habitats. Understanding the environment and faunal adaptations may help explain how the recently discovered anomalous campodeid survived beneath the glacier (Sendra and Wagnell 2019).

\section{SUGGESTED COLLECTION METHODS}

Biological surveys of caves can be challenging both physically and logistically (Wynne et al., 2019). Fortunately, improved equipment and training have made exploring caves and conducting research safer and more productive. Furthermore, protocols for biological surveys have evolved and become more standardized (Hunt and Millar, 2001; Culver and Sket, 2002; Wynne et al. 2019). These methods can be utilized or modified for surveying glacial caves; however, 
because of the additional risks inherent in exploring glacial caves, it seems prudent that the initial reconnaissance surveys employ passive collecting techniques that can be deployed remotely or quickly in accessible locations. For example, for terrestrial habitats, baited pitfall traps, including mesocavern traps (López and Oromí, 2010) could be lowered by rope into crevasses that reach the substrate. For aquatic habitats, plankton nets and baited shrimp traps could be lowered into waterways. Where possible, traps can be placed in and along the margins of springs exiting glaciers. This latter strategy should include surveys of the volume and composition of organic material released from the glacier. In addition, biologists might collaborate with glaciologists and utilize the holes drilled into glaciers. The results from these reconnaissance surveys will indicate which accessible caves would be suitable for more intensive surveys.

\section{CONCLUSIONS}

The fauna and microbiome of caves occurring in and beneath glacial ice are poorly known, and their ecology little understood. The few studies done to date indicate that a diverse fauna exists, which includes narrowly endemic species. Research in glacial caves is difficult due to the harsh environment and dynamic nature of the caves. Nevertheless, biodiversity and ecological studies are valuable and potentially improve our understanding of how organisms adapt to harsh environments. Glaciers and their associated habitats are disappearing at alarming rates. Glacial caves harbor one of the most endangered ecosystems on earth. Without successful mitigation to reverse global warming and limit the loss of montane glaciers, most glaciers, along with their associated fauna, will disappear in the next few decades.

\section{REFERENCES}

Anesio, A.M., Lutz, S., Chrismas, N.A.M., and Benning, L.G., 2017, The microbiome of glaciers and ice sheets: npj Biofilms and Microbiomes, v. 3 no. 10, p. 12537-2549. https://doi.org/10.1038/s41522-017-0019-0.

Bhatia, M., Sharp, M., and Foght, J., 2006, Distinct bacterial communities exist beneath a high Arctic polythermal glacier: Applied and Environmental Microbiology, v. 7, no. 9, p. 5838-5845. https://doi.org/10.1128/AEM.00595-06.

Brown, L.E., Hannah, D.M., and Milner, A.M., 2007, Vulnerability of alpine stream biodiversity to shrinking glaciers and snowpacks: Global Change Biology, v. 13, p. 958-966. https://doi.org/10.1111/j.1365-2486.2007.01341.x.

Cartaya, E.L., and McGregor, B., 2014, The Sandy Glacier Cave Project: the study of glacial recession from within: in Lewis L., Kern, Z., Maggi, V., and Turri, S., eds., Proceedings of the Sixth International Workshop on Ice Caves, August 17-22, Idaho Falls, Idaho, USA: National Cave and Karst Research Institute (NCKRI) Symposium 4. Carlsbad (N.M.),

Culver, D.C., and Sket, B., 2002, Biological monitoring in caves: Acta Carsologica, v. 31, p. 55-64. https://doi.org/10.3986/ac.v31i1.403.

Edwards, J.S., 1987, Arthropods of alpine aeolian ecosystems: Annual Review of. Entomology, v. 32, p. 163-179. https://doi.org/10.1146/annurev. en.32.010187.001115.

Faria, C.M.A., Shaw, P., and Emerson, B.C., 2019, Evidence for the Pleistocene persistence of Collembola in Great Britain: Journal of Biogeography, v. 46, p. 14791493. https://doi.org/10.1111/jbi.13610

Ficetola, G.F., Canedoli, C., and Stoch, F., 2018, The Racovitzan impediment and the hidden biodiversity of unexplored environments: Conservation Biology, v. 33, p. 214-216. https://doi.org/10.1111/jbi.13610.

Giersch, J.J., Hotaling, S., Kovach, R.P., Jones, L.A., Muhlfeld, C.C., 2016, Climate-induced glacier and snow loss imperils alpine stream insects: Global Change Biology, v. 23, p. 25772589.

Giersch, J.J., Jordan, S., Luikart, G., Jones, L.A., Hauer, F.R., and Muhlfeld, C.C., 2015, Climate-induced range contraction of a rare alpine aquatic invertebrate: Freshwater Science, v. 34, p. 53-65. https://doi.org/10.1086/679490.

Giggenbach, W.F., 1976, Geothermal ice caves on Mt Erebus, Ross Island, Antarctica: New Zealand Journal of Geology and Geophysics, v. 19 no. 3, p. 365-372. https://doi.org/10.1080/00288306.1976.10423566.

Gulley, J.D., and Fountain, A.G., 2019, Glacier caves. in Culver, D.C., and W. White, W. eds., Encyclopedia of Caves, Elsevier Academic Press, Burlington, Mass, 3rd ed., p. 468-473. https://doi.org/10.1016/B978-0-12-814124-3.00056-X.

Hall, M.H.P., and Fagre, D.B., 2003, Modeled climate-induced glacier change in Glacier National Park, 1850-2100: BioScience, v. 53, p. 131-140. https://doi.org/10.1641/0006-3568(2003)053[0131:MCIGCI]2.0.CO;2.

Hamerlik, L., and Jacobsen, D., 2011, Chironomid (Diptera) distribution and diversity in Tibetan streams with different glacial influence: Insect Conservation and Diversity, v. 5, p. 319-326. https://doi.org/10.1111/j.1752-4598.2011.00167.x.

Hodson, A., Brock, B., Pearce, D., Laybourn-Parry, J., and Tranter, M., 2015, Cryospheric ecosystems: a synthesis of snowpack and glacial research: Environmental Research Letters, v. 10 p. 17. https://doi.org/10.1088/1748-9326/10/11/110201.

Hotaling, S., Finn, D.S. Giersch, J.J., Weisrock, D.W., and Jacobsen, D., 2017a, Climate change and alpine stream biology: progress, challenges, and opportunities for the future: Biological Reviews, v. 92, p. 2024-2045. https://doi.org/10.1111/brv.12319.

Hotaling, S, Hood, E., and Hamilton, T.L., 2017b, Microbial ecology of mountain glacier ecosystems: biodiversity, ecological connections and implications of a warming climate: Environmental Microbiology, v. 19, 8, p. 2935-2948. https://doi.org/10.1111/1462-2920.13766.

Hotaling, S., Shain, D.H., Lang, S.A., Bagley, R.K., L.M. Tronstad, L.M., Weisrock, D.W., and Kelley, J.L., 2019, Long-distance dispersal, ice sheet dynamics and mountaintop isolation underlie the genetic structure of glacier ice worms: Proceedings of the Royal Society B: Biological Sciences, v. 286, p. 20190983. http://doi.org/10.1098/rspb.2019.0983.

Howarth, F.G., 1972, Cavernicoles in lava tubes on the island of Hawaii: Science, v. 75, p. 325-326. https://doi.org/10.1126/science.175.4019.325.

Howarth, F.G., 1983, The ecology of cave arthropods: Annual Review of Entomology, v. 28, p. 365-389. https://doi.org/10.1146/annurev. en.28.010183.002053.

Howarth, F.G., Hoch. H., and Wessel, A, 2019, Adaptive shifts. in Culver, D.C., and White, W. eds., Encyclopedia of Caves, 3rd ed., Elsevier Academic Press, Burlington, Mass., p. 47-55. https://doi.org/10.1016/B978-0-12-814124-3.00007-8.

Howarth, F.G., and Moldovan, O.T., 2018, Where cave animals live: Chapter 3, in Moldovan, O.T., Kováč, L'., and Halse, S. eds., Cave Ecology. Springer, Switzerland, p. 23-37. https://doi.org/10.1007/978-3-319-98852-8_3.

Hunt, M., and Millar, I., 2001, Cave Invertebrate Collecting Guide: New Zealand Department of Conservation Technical Series, no. 26, p. 1-28. 
lepure, S., 2018, Ice cave fauna: a concise review: Chapter 7, in Perşoiu, A., and Lauritzen, S.-E. eds., Ice Caves. Elsevier Inc., Netherlands, p. 163-171. https://doi.org/10.1016/B978-0-12-811739-2.00007-3.

Jacobsen, D., Dangles, O., Andino, P., Espinosa, R., Hamerlik, L., and Cadier, E., 2010, Longitudinal zonation of macroinvertebrates in an Ecuadorian glacier-fed stream: Do tropical glacial systems fit the model?: Freshwater Biology, v. 55. p. 1234-1248, https://doi.org/10.1111/j.13652427.2009.02348.x.

Jacobsen, D, Milner AM, Brown LE, and Dangles, O., 2012, Biodiversity under threat in glacier-fed river systems: Nature Climate Change, 2012, v. 2, p. 361-364. https://doi.org/10.1038/nclimate1435.

Jordan, S., Giersch, J.J., Muhlfeld, C.C., Hotaling, S., Fanning, L., Tappenbeck, T.H., and Luikart, G., 2016, Loss of genetic diversity and increased subdivision in an endemic alpine stonefly threatened by climate change: PLoS ONE, v. 11(6): p. 1-12. e0157386. https://doi. org/10.1371/journal.pone.0157386.

Kiver, E.P., and Mumma, M.D., 1971, Summit firn caves, Mt Rainier, Washington: Science, v. 173, p. 320322. https://doi.org/10.1126/science.173.3994.320.

Kondratieff, B.C., and Lechleitner, R.A., 2002, Stoneflies (Plecoptera) of Mount Rainier National Park, Washington: Western North American Naturalist, v. 62, p. 385-404.

Kornobis, E., Pálsson, S., Kristjánsson, B.K., and Svavarsson, J., 2010, Molecular evidence of the survival of subterranean amphipods (Arthropoda) during Ice Age underneath glaciers in Iceland: Molecular Ecology, v. 19, p. 2516-2530. https://doi.org/10.1111/j.1365-294X.2010.04663.x.

Kováč, L.., 2018, Ice Caves: Chapter 15, in Moldovan, O.T., Kováč, L'., and Halse, S. eds., Cave Ecology. Springer, Switzerland. pp 331-349. https://doi.org/10.1007/978-3-319-98852-8_15.

Kubo, J.S., Torgersen, C.E., Bolton, S.M., Weekes, A.A., and Gara, R.I., 2012, Aquatic insect assemblages associated with subalpine stream segment types in relict glaciated headwaters: Insect Conservation and Diversity, v. 6 p. 422-434. https://doi.org/10.1111/j.17524598.2012.00210.x.

Lockwood, J.A, Thompson, C.D., Debrey, L.D., Love, C.M., and Nunamaker, R.A., 1991, Preserved grasshopper fauna of Knife Point Glacier, Fremont County, Wyoming, U.S.A.: Arctic and Alpine Research, v. 23, p. 108-114. https://doi.org/10.2307/1551444.

López, H., and Oromí, P., 2010, A pitfall trap for sampling the mesovoid shallow substratum (MSS) fauna: Speleobiology Notes, v. 2, p. 7-11.

Mani, M.S., 1968, Ecology and Biogeography of High Altitude Insects: Series Entomologica Vol. 4. Junk, W., N.V. Publishers, The Hague. https:// doi.org/10.1007/978-94-017-1339-9.

Maurer, J. M., Schaefer, J.M., Rupper, S., and Corley A., 2019, Acceleration of ice loss across the Himalayas over the past 40 years: Science Advances, v. 2019;5: eaav7266, p. 112. https://doi.org/10.1126/sciadv.aav7266.

Mclnemey, C.E., Maurcie, I., Robertson, A.L., Knight, L.R.F.D., Arnscheidt, J., Venditto, C., Dooley, J.S.G., Mathers, T., Matthijs, S., Eriksson, K. Proudlove, G.S. and Hänfling, B. 2014, The ancient Britons: groundwater fauna survived extreme climate change over tens of millions of years across NW Europe: Molecular Ecology, 23, no. 5, p. 1153-1166. https://doi.org/10.1111/mec.12664.

Mikucki, J.A., Pearson, A., Johnston, D.T., Turchyn, A., Farquhar, J., Schrag, D.P., Anbar, A.D., Priscu, J.C., and Lee, P.A. 2009, A contemporary microbially maintained subglacial ferrous "ocean:" Science, v. 324, p. 397-400. https://doi.org/10.1126/science.1167350.

Milner, A.M., Taylor, R.C., and Winterbourn, M.J., 2001, Longitudinal distribution of macroinvertebrates in two glacier-fed New Zealand rivers: Freshwater Biology, v. 46, p. 1765-1775. https://doi.org/10.1046/j.1365-2427.2001.00856.x.

Muhlfeld, C.C., Giersch, J.J., Hauer, F.R., Pederson, G.T., Luikart, G., Peterson, D.P., Downs, C.C., and Fagre, D.B. 2011, Climate change links fate of glaciers and an endemic alpine invertebrate: Climate Change, v. 106, p. 337-345. https://doi.org/10.1007/s10584-011-0057-1.

Papp, R.P., 1978, A nival aeolian ecosystem in California: Arctic and Alpine Research, v. 10, p. 117-131. https://doi.org/10.2307/1550661.

Piccini, L., and Mecchia M., 2013, Englacial caves of Glaciar Perito Moreno and Glaciar Ameghino, Patagonia (Argentina): in Filipi, M., and Bozac, P. eds., $16^{\text {th }}$ International Congress Speleology, Proceedings, Vol 3. Brno, p. 292-297.

Scotti, A., Tappeiner, U., and Bottarin R., 2019, Stream benthic macroinvertebrates abundances over a 6-year monitoring period of an Italian glacier-fed stream: Biodiversity Data Journal, v. 7. https://doi.org/10.3897/BDJ.7.e33576.

Sendra, A., and Wagnell, C., 2019, The cave-dwelling dipluran (Diplura, Campodeidae) on the edge of the last glacial maximum in Vancouver Island caves, North America (Canada): Subterranean Biology, v. 29, no. 4, p. 59-77. https://doi.org/10.3897/subtbiol.29.31467.

Shain, D.H., Halldórsdóttir, K., Pálsson,F., Aðalgeirsdóttir, G., Gunnarsson, A., Jónsson. P., Lang, S.A., Pálsson, S.H., Steinpórssson, S., and Arnasone, E. 2016. Colonization of maritime glacier ice by bdelloid Rotifera. Molecular Phylogenetics and Evolution, v. 98, p. 280-287. https:// doi.org/10.1016/j.ympev.2016.02.020.

Smart, C., 2003, Glacier caves and glacier pseudokarst: in Gunn, J., ed., Encyclopedia of Caves and Karst Science, Routledge, London, p. 385-387.

Swan, L.W., 1992, The aeolian Biome: BioScience, v. 42, p. 262-270. https://doi.org/10.2307/1311674.

Takeuchi, N., 2011, Glacial ecosystems: in Encyclopedia of Snow, Ice and Glaciers: Singh, V.P., Singh, P., and Haritashya, U.K., eds., The Netherlands: Springer Science. p. 330-331. https://doi.org/10.1007/978-90-481-2642-2_608.

Taylor, S.J., and Niemiller, M.L., 2016, Biogeography and conservation assessment of Bactrurus groundwater amphipods (Crangonyctidae) in the central and eastern United States: Subterranean Biology, v. 17, p. 1-29. https://doi.org/10.3897/subtbiol.17.7298.

Vanlooy, J.A., and Vandeberg, G.S., 2019, Late summer glacial meltwater contributions to Bull Lake Creek stream flow and water quality, Wind River Range, Wyoming, USA: Physical Geography, v. 40, p. -10.1080/02723646.2019.1565215, (120). https://doi.org/10.1080/02723646.2019. 1565215.

Winterbourn, M.J., Cadbury, S., Ilg, C., and Milner, A.M., 2008, Mayfly production in a New Zealand glacial stream and the potential effect of climate change: Hydrobiologia, v. 603, p. 211-219. https://doi.org/10.1007/s10750-007-9273-0.

Wipfler, B., Bai, M., Schoville, S., Dallai, R., Uchifune, T., Machida, R., Cui, Y., and Beutel, R. 2014, Ice Crawlers (Grylloblattodea) - the history of the investigation of a highly unusual group of insects: Journal of Insect Biodiversity, v. 2, p. 1-25. https://doi.org/10.12976/jib/2014.2.2.

Wynne, J.J., Howarth, F.G., Sommer, S., and Dickson, B.G., 2019, Fifty years of cave arthropod sampling: techniques and best practices: International Journal of Speleology, v. 48, p. 33-48. https://doi.org/10.12976/jib/2014.2.2.

Templeton, A., and Jahn E., 2019, Thin Ice-Exploring Mount Hood's Glacier Caves. https://www.opb.org/glaciercaves/ [Retrieved September 10, 2019].

Zawierucha, K., Kolicka, M., Takeuchi, N., and Kaczmarek, Ł., 2015, What animals can live in cryoconite holes? A faunal review: Journal of Zoology, v. 295, p. 159-169. https://doi.org/10.1111/jzo.12195.

Zawierucha, K., and Shain, D.H., 2019, Disappearing Kilimanjaro snow-Are we the last generation to explore equatorial glacier biodiversity?: Ecology and Evolution, v. 9, p. 8911-8918. https://doi.org/10.1002/ece3.5327. 